Pavel Larionov*, MA, https:/ / orcid.org/0000-0002-4911-3984

Karolina Mudło-Głagolska*, MA, https:/ / orcid.org/0000-0001-8079-3781

* Kazimierz Wielki University

in Bydgoszcz

\title{
Cognitive coping strategies and aggression in adolescents
}

\author{
Poznawcze strategie radzenia sobie ze stresem \\ a agresja $u$ adolescentów ${ }^{1}$ \\ https://doi.org/10.34766/ fetr.v47i3.767
}

\begin{abstract}
The analysis of psychological factors associated with aggressive behavior of adolescents is an important area of research. The aim of this study is to identify the relationships between cognitive emotion regulation strategies and physical aggression, anger and hostility in Polish and Ukrainian adolescents. The study involved 70 Polish and 63 Ukrainian teenagers aged 11 to 15 . The research tools used in the study included the Cognitive Emotion Regulation Questionnaire and the Buss-Perry Aggression Questionnaire. It has been found that primarily maladaptive strategies are strongly associated with hostility and to a somewhat lesser extent with anger. Boys and girls hardly differ in the results of the studied variables within their cultures, which may indicate that gender does not differentiate the level of aggression and the frequency of using cognitive coping strategies. On the basis of the obtained results, it may be concluded that the main focus of preventive measures should be the development of effective coping skills. They should aim primarily at reducing the use of maladaptive cognitive emotion regulation strategies such as self-blame, catastrophizing, rumination and blaming others.
\end{abstract}

Keywords: adolescence, aggression, hostility, anger, cognitive coping strategies, emotion regulation, risk factor.

Abstrakt: Analiza czynników psychologicznych związanych z zachowaniami agresywnymi adolescentów stanowi ważny obszar badań. Celem badań było określenie związków między poznawczymi strategiami regulacji emocji a agresją fizyczną, gniewem i wrogością u polskich i ukraińskich adolescentów. W badaniu wzięło udział 70 adolescentów z Polski oraz 63 z Ukrainy w wieku od 11 do 15 lat. Wykorzystane narzędzia badawcze to Kwestionariusz Poznawczej Regulacji Emocji oraz Kwestionariusz Agresji Bussa-Perry' ego. Wykazano, że przede wszystkim strategie nieadaptacyjne były silnie związane z wrogością i w nieco mniejszym stopniu z gniewem. Chłopcy i dziewczynki wewnątrz swoich grup narodowościowych prawie nie różnili się pod względem wyników badanych zmiennych, co może świadczyć o tym, że płeć nie różnicuje poziomu agresji i częstotliwości wykorzystania poznawczych strategii radzenia sobie. Na podstawie uzyskanych wyników można stwierdzić, że głównym celem działań profilaktycznych powinien być rozwój umiejętności skutecznego radzenia sobie skierowany przede wszystkim na redukcję stosowania nieadaptacyjnych strategii regulacji emocji, takich jak obwinianie siebie, katastrofizowanie, ruminowanie i obwinianie innych.

Słowa kluczowe: adolescencja, agresja, wrogość, gniew, poznawcze strategie radzenia sobie ze stresem, regulacja emocji, czynniki ryzyka.

1 Polska wersja: https:/ / stowarzyszeniefidesetratio.pl/Presentations0/2021-3-Lari.pdf 


\section{Introduction}

Modern civilization increasingly manifests the features of a violent civilization. Aggression among children and adults has become a global social problem (Pikuła, 2012). Aggressive behavior among teenagers is most often expressed through peer violence, bullying and cyberbullying. The Programme for International Student Assessment PISA 2018 found out that on average $26 \%$ of Polish teenagers aged 15 experienced bullying (OECD, 2019). Although the level of bullying in Poland is mediocre compared to other European countries, according to a report by the World Health Organization (WHO), Poland holds one of the dominant positions in the ranking of the cyberbullying prevalence among adolescents aged 11-15 (Inchley et al., 2020).

In response to the escalation of dysfunctional behavior of students, including aggressive behavior, the following documents were released: Regulation of the Minister of National Education, amending the regulation on the principles of providing and organizing psychological and pedagogical assistance in public kindergartens, schools and other institutions, issued on 28 August 2017 (Dz. U. of 31 August 2017, item 1643) and the Regulation of the Minister of National Education and Sport, concerning safety and hygiene in public and non-public schools and institutions, issued on 31 October 2018 (Dz. U. of 2018, item 2140, as amended). They impose, among others, the obligation to include appropriate entries concerning preventive measures in the documents (e.g. School Statute, UpbringingProphylactic Programme).

Analyzing the causes of adolescent aggressive behavior is an important area of both scientific and practical research. WHO (2014) proposes to make efforts in order to prevent violence and aggression. At the intrapsychic level, WHO (2009) recommends the development of life skills that will enable individuals to cope effectively with the demands and challenges of their daily lives. With increasing prevalence of aggressive behavior among adolescents, the identification of appropriate aggression prevention methods is of great importance (Porzak, 2019).

\section{Aggression and its definitions}

Many definitions and theories of aggression have been presented, describing its nature and forms, as well as its formation mechanisms (Archer, 2009; Benjamin, 2016). A multidimensional definition of aggression was presented by Polish psychologist Gaś as "a set of experiences, attitudes and behaviors whose purpose or effect is to cause harm (directly or indirectly) to another person or to oneself. The syndrome of aggression includes both aggressive tendencies and unconscious inclinations, manifested externally or directed at 
oneself" (Gaś, 1980, p. 143). Aggression can be targeted both directly against other living organisms or inanimate objects and against oneself (self-aggression). There is a distinction between direct aggression (it is expressed in aggressive behavior of the aggressor towards the victim during direct contact) and indirect aggression (no direct contact). Direct aggression manifests itself, for example, in hitting the victim, while indirect aggression manifests itself in spreading rumors about someone (Jhangiani \& Tarry, 2014).

It is important to emphasize the necessity of distinguishing between the two types of aggression, which are based on different psychological mechanisms: impulsive (emotional or reactive) and instrumental (cognitive or proactive) aggression. Impulsive aggression has little to do with a conscious intention to pursue aggressive behavior and it is manifested in an impulsive response to an aggression-inducing factor (e.g., a response to a provocation). Instrumental aggression is conscious and intentional and it is associated with gaining benefit (Jhangiani \& Tarry, 2014).

Buss and Perry (1993) distinguished four forms of aggression: (1) physical and (2) verbal aggression, which are the behavioral components of aggression, (3) anger (emotional component), and (4) hostility (cognitive component). The above-mentioned classification of aggression forms is very useful within the framework of applied research, as it allows to assess varied tendencies to respond aggressively. This classification has been recognized by researchers worldwide, and the Aggression Questionnaire developed by Buss and Perry to measure these four forms of aggression has become the gold standard in research on aggression in various age groups (Aranowska \& Rytel, 2012).

\section{Factors associated with adolescent aggression}

Numerous studies have shown that certain biological factors (e.g. specific set of temperament traits, the so-called difficult temperament), psychological (ineffective stress coping) and social (specific atmosphere in the family and school, characterized by excessive rigor and restrictions, organizational chaos) are related to aggressive behavior (BorzuckaSitkiewicz, 2010; Damięcka, 2003; Kowalczuk, Jankowiak, Krajewska-Kułak, Rolka, \& Sierakowska, 2011; Przybysz-Zaremba, 2015). Valois et al. (2002) noted that prevention activities should be based on a theory that takes into account the presence of various risk factors associated with the formation and manifestation of aggression in adolescents. Thus, important directions of scientific research are to be explored by the representatives of psychological science: (1) the study of personality factors predisposing to aggression, (2) the search for psychosocial factors provoking the formation of aggressive reactions, (3) the development of effective methods of psychological assistance to adolescents prone to aggressive behavior, and (4) the implementation of programmes to prevent aggression among children and adolescents (Larionov \& Grechukha, 2020). 
Berkowitz's (1993) work - a reformulated frustration-aggression theory - can serve as a theoretical basis for the above-mentioned goals. According to this theory, aggression is a natural reaction that can occur in situations of deprivation or perceived inability to satisfy current needs. It should be emphasized that stressors that cause psycho-emotional tension, increase the probability of aggression, but do not necessarily lead to the appearance of aggressive behavior (Borzucka-Sitkiewicz, 2010). There is plenty of evidence indicating the presence of a relationship between inadequate emotion regulation or coping with difficult situations and aggression (Roberton, Daffern, \& Bucks, 2012). In this regard, we can cite the definition of "aggressive behavior" presented by Sołtys and Grzankowska. According to them, aggressive behavior is "an abnormal form of coping with negative emotional arousal due to difficulties in emotion regulation and cognitive control" (Sołtys \& Grzankowska, p. 204).

\section{Emotion regulation and stress management in relation to aggression}

During puberty, adolescents are often characterized by high emotional lability, they experience discomfort due to hormonal changes, and are in a state of psychological developmental crisis (Becelewska, 2006). Difficulties in emotion regulation and coping with unpleasant situations are a significant problem for the well-being of adolescents (Modecki, Zimmer-Gembeck, \& Guerra, 2017). A significant correlation has been observed between dysfunctional emotion regulation and aggression among adults (Contardi, Imperatori, Penzo, Del Gatto, \& Farina, 2016; Donahue, Goranson, McClure, \& Van Male, 2014). Research has shown that the use of adaptive emotion regulation strategies (e.g., problem solving, distraction) was associated with a lower probability of aggressive behavior among adolescents (Calvete \& Orue, 2012). It was also reported that appropriate emotion regulation in difficult situations moderates the relationship between anger and reactive aggression among adolescents. From a psychological perspective, these findings reflect the following pattern: an adolescent characterized by effective stress coping will demonstrate a weaker tendency to react aggressively while experiencing anger (Calvete \& Orue, 2012). Cognitive coping strategies such as self-blame and rumination are significant predictors of physical-verbal aggression in boys (Rey \& Extremera, 2012). McLaughlin, Hatzenbuehler, Mennin, and Nolen-Hoeksema (2011) noted that emotional dysregulation (expressed in poor understanding of emotions, violation of sadness and anger expression and rumination) is a significant predictor of the development of psychopathology and aggressive behavior among adolescents. It has been shown that adolescents with internalizing problems are more characterized by the use of maladaptive cognitive coping strategies such as self-blame and rumination compared to adolescents without these problems (Garnefski, Kraaij, \& van Etten, 2005). Based on these studies, it can be 
concluded that dysfunctional emotion regulation and maladaptive coping are risk factors for aggressive behavior among adolescents.

\section{Aims and Hypotheses of the Research}

Based on the above-described studies showing that emotion regulation is related to the occurrence of aggression among adolescents, this study is aimed at determining which emotion regulation strategies are related to aggression and its forms among Polish adolescents. In addition, it has been planned to examine the occurrence of similar correlation in a sample of Ukrainian adolescents in order to test the universal nature of these relationships in two samples.

The research is based on the concept of emotion regulation by Garnefski, Kraaij, and Spinhoven (2001), according to which, there are two types of emotion regulation strategies that a person uses when experiencing difficult situations: cognitive strategies (what do I think?) and behavioral strategies (what do I do?) (Garnefski, Kraaij, \& Spinhoven, 2002; Marszał-Wiśniewska \& Fajkowska, 2010). Such a distinction is based on the assumption that cognitive activity, firstly, differs from behavioral activity, which is expressed in an individual's coping actions. Secondly, cognitive coping precedes behavioral coping (although it does not necessarily lead to its realization) (Marszał-Wiśniewska \& Fajkowska, 2010). Garnefski et al. (2001) developed the Cognitive Emotion Regulation Questionnaire to assess the frequency of nine cognitive emotion regulation strategies used when experiencing negative or unpleasant events. In this regard, the theory by Garnefski et al. equates emotion regulation strategies with stress coping strategies. There are five adaptive strategies (acceptance, refocusing on planning, positive refocusing, positive reappraisal, and putting into perspective) and four maladaptive strategies (self-blame, blaming others, rumination, and catastrophizing). Conducting research within the theoretical framework by Garnefski et al. (2001) allows for the identification of a broad type of cognitive coping strategies that are described in detail.

Considering that cognitive coping strategies precede behavioural strategies, conducting research to develop psychological assistance programmes for adolescents experiencing aggression is becoming necessary. Thus, the study of cognitive emotion regulation strategies becomes important for prevention efforts, as well as psychological intervention aimed at developing coping skills (Jurczyk, 2018; Sukhodolsky, Smith, McCauley, Ibrahim, \& Piasecka, 2016).

The aim of the study is to determine the relationship between cognitive emotion regulation strategies and physical aggression, anger, and hostility in Polish and Ukrainian adolescents. 


\section{Method}

\subsection{Study samples and procedure}

The sample of Polish adolescents consisted of 70 individuals aged 11 to 14 (M=12.49, $\mathrm{SD}=0.98$ ), including $51.43 \%$ boys and $44.29 \%$ girls. The remaining students did not indicate their gender. The number of seventh grade students amounted to $47.14 \%$ of the sample, the number of sixth grade students was $38.57 \%$, and eighth grade students made up $14.29 \%$. The sample of Ukrainian students consisted of 63 individuals aged 12 to 15 ( $M=14.54, S D=0.88$ ), among whom there were $68.25 \%$ girls and $31.75 \%$ boys. The survey of Polish adolescents was conducted during project hours in one of elementary schools in Wielkopolska Voivodeship. To complete the questionnaires, the time given was approximately 15 minutes. The results of the Ukrainian sample come from studies previously conducted as part of research projects describing the role of alexithymia and emotion dysregulation in the development of aggression among adolescents (Larionov \& Grechukha, 2020).

\subsection{Research tools}

The Cognitive Emotion Regulation Questionnaire (CERQ) by Garnefski et al. (2001) in its Polish adaptation by Marszał-Wiśniewska and Fajkowska was used (2010). The CERQ assesses the frequency of nine cognitive coping strategies that a person uses when experiencing negative or unpleasant events. The CERQ consists of nine subscales, each containing four items (the CERQ has 36 items). The nine subscales reflect individual cognitive coping strategies, five of which are adaptive strategies (acceptance, refocusing on planning, positive refocusing, positive reappraisal, and putting into perspective), whereas four are maladaptive strategies (self-blame, blaming others, rumination, and catastrophizing). There is a five-point scale for response ranging from 1 (almost) never to 5 (almost) always. Scores can be calculated for each strategy separately, as well as an average score for all adaptive and maladaptive strategies. A high score indicates more frequent use of stress coping strategies (Marszal-Wiśniewska \& Fajkowska, 2010). In the study of the Ukrainian sample, the validated Russian version of CERQ was used (Rasskazova, Leonova, \& Pluzhnikov, 2011).

The Buss-Perry Aggression Questionnaire (BPAQ) by Buss and Perry (1993) in the Polish adaptation by Aranowska, Rytel and Szymańska was also used (2015). The BPAQ allows to assess the severity of four indicators of aggression: Physical Aggression, Verbal Aggression, Anger and Hostility, and overall aggression score. The BPAQ questionnaire contains 29 items, among which five items belong to the verbal aggression scale, nine to Physical Aggression, seven to Anger, and eight to Hostility. There is a five-point scale for response ranging from 1 (extremely uncharacteristic) to 5 (extremely characteristic). Two items use reverse scaling. The study of the Ukrainian sample used the Russian version of the BPAQ adapted 
by Enikolopov and Tsibul'ski (2007). The Russian version of the questionnaire consists of 24 items and does not include the Verbal Aggression scale, which was dropped during the validation study.

\section{Results}

Table 1 presents means, standard deviations and Cronbach's alpha coefficients ( $\alpha$ ) of examined variables in the samples of Polish and Ukrainian adolescents. The reliability of most of the tested variables was satisfactory ( $\alpha$ above 0.6 ). In the Polish sample, two variables had low reliability: self-blame $(\alpha=0.48)$ and putting into perspective $(\alpha=0.51)$. In the Ukrainian sample, two variables also had low reliability: blaming others $(a=0.37)$ and refocusing on planning $(\mathrm{a}=0.54)$. Considering the fact that the present study is a non-clinical one involving adolescents, and that each of these variables contains four statements in the CERQ questionnaire, the relatively low reliability of these variables can be considered sufficient for the purpose of this study.

Table 1. Means, standard deviations and Cronbach's alpha (a) coefficients of the examined variables in the samples of Polish $(n=70)$ and Ukrainian adolescents $(n=63)$

\begin{tabular}{|l|c|c|c|c|c|c|}
\hline \multirow{2}{*}{\multicolumn{1}{c|}{ Variables }} & \multicolumn{3}{c}{ Poland } & \multicolumn{3}{c|}{ Ukraine } \\
\cline { 2 - 7 } & $\mathrm{a}$ & $M$ & $S D$ & $\mathrm{a}$ & $M$ & $S D$ \\
\hline Self-blame & 0.48 & 9.96 & 2.79 & 0.76 & 10.89 & 3.47 \\
\hline Rumination & 0.78 & 11.00 & 3.77 & 0.77 & 11.75 & 3.77 \\
\hline Catastrophizing & 0.72 & 10.26 & 3.59 & 0.60 & 7.59 & 2.57 \\
\hline Blaming others & 0.71 & 9.11 & 3.47 & 0.37 & 8.24 & 2.05 \\
\hline Maladaptive strategies & 0.85 & 40.33 & 10.55 & 0.77 & 38.46 & 8.01 \\
\hline Acceptance & 0.72 & 12.01 & 3.57 & 0.66 & 11.54 & 3.33 \\
\hline Positive refocusing & 0.84 & 12.06 & 4.07 & 0.60 & 11.02 & 3.04 \\
\hline Refocusing on planning & 0.66 & 11.91 & 3.42 & 0.54 & 12.67 & 2.97 \\
\hline Positive reappraisal & 0.68 & 11.40 & 3.58 & 0.73 & 12.95 & 3.31 \\
\hline Putting into perspective & 0.51 & 11.90 & 3.16 & 0.61 & 10.98 & 3.14 \\
\hline Adaptive strategies & 0.86 & 59.29 & 13.03 & 0.83 & 59.16 & 11.05 \\
\hline Physical aggression & 0.74 & 23.20 & 6.59 & 0.80 & 18.59 & 6.18 \\
\hline Anger & 0.69 & 18.10 & 5.34 & 0.74 & 21.17 & 5.39 \\
\hline Hostility & 0.78 & 23.91 & 6.82 & 0.72 & 21.54 & 5.93 \\
\hline
\end{tabular}

It was examined whether boys and girls differed in the results of the studied variables, separately for the Polish and Ukrainian population samples. The analysis showed 
that in the group of Polish adolescents, boys had significantly higher physical aggression scores (boys: $\mathrm{M}=25.65, \mathrm{SD}=5.86$, girls: $\mathrm{M}=21.33, \mathrm{SD}=6.78$; $\mathrm{t}=2.76 \mathrm{p}=0.007$ ). However, in the group of Ukrainian adolescents, girls scored significantly higher than boys in one of the emotion regulation strategies - rumination (girls: $\mathrm{M}=12.40, \mathrm{SD}=3.53$, boys: $\mathrm{M}=10.35$, $\mathrm{SD}=1.26 ; \mathrm{t}=2.06, \mathrm{p}=0.044)$.

Table 2. Analysis of correlations (r-Pearson) between emotion regulation strategies and aggression subscales in the samples of Polish $(n=70)$ and Ukrainian adolescents $(n=63)$

\begin{tabular}{|l|c|c|c|c|c|c|}
\hline \multirow{2}{*}{ Variables } & \multicolumn{3}{|c|}{ Poland } & \multicolumn{3}{c|}{ Ukraine } \\
\cline { 2 - 7 } & PA & Anger & Hostility & PA & Anger & Hostility \\
\hline Self-blame & $0.31^{* *}$ & $0.39^{* * *}$ & $0.60^{* * *}$ & -0.15 & 0.20 & $0.25^{*}$ \\
\hline Rumination & 0.14 & $0.37^{* *}$ & $0.58^{* * *}$ & -0.10 & $0.35^{* *}$ & $0.44^{* * *}$ \\
\hline Catastrophizing & 0.10 & $0.36^{* *}$ & $0.50^{* * *}$ & 0.20 & $0.44^{* * *}$ & $0.45^{* * *}$ \\
\hline Blaming others & 0.19 & $0.38^{* * *}$ & $0.36^{* *}$ & 0.12 & 0.17 & 0.02 \\
\hline Maladaptive strategies & 0.23 & $0.48^{* * *}$ & $0.66^{* * *}$ & -0.01 & $0.43^{* * *}$ & $0.47^{* * *}$ \\
\hline Acceptance & 0.10 & $0.34^{* *}$ & $0.41^{* * *}$ & 0.13 & 0.21 & 0.10 \\
\hline Positive refocusing & -0.20 & 0.10 & 0.08 & -0.04 & $0.28^{*}$ & 0.10 \\
\hline $\begin{array}{l}\text { Refocusing on } \\
\text { planning }\end{array}$ & -0.19 & -0.16 & 0.02 & -0.01 & 0.18 & -0.06 \\
\hline Positive reappraisal & $-0.24^{*}$ & -0.13 & -0.13 & -0.14 & 0.02 & $-0.28^{*}$ \\
\hline $\begin{array}{l}\text { Putting into } \\
\text { perspective }\end{array}$ & -0.12 & 0.04 & 0.10 & 0.20 & 0.13 & -0.03 \\
\hline Adaptive strategies & -0.18 & 0.06 & 0.14 & 0.04 & 0.23 & -0.05 \\
\hline
\end{tabular}

Annotation. ${ }^{*} p<0,05 ;{ }^{* *} p<0,01 ; p<0,001$. PA - Physical aggression.

Subsequently, the focus was put on the direction and strength of the correlation between emotion regulation strategies and subscales of aggression, separately in samples of Polish and Ukrainian adolescents.

A sample of Polish adolescents showed a statistically significant positive relationship between self-blame, rumination, catastrophizing, as well as the total score of maladaptive strategies, and hostility. Blaming others was positively related to hostility. There was also a positive correlation between self-blame and physical aggression. Self-blame, rumination, catastrophizing, blaming others, and the total score of maladaptive strategies were positively related to anger. Adaptive strategy "acceptance" was positively related to hostility and anger. Positive reappraisal was negatively related to physical aggression. The detailed results are presented in Table 2.

Results indicated that in the Polish sample, all maladaptive emotion regulation strategies were positively related to anger and hostility, whereas adaptive strategies were not 
significantly related to these dimensions of aggression (except acceptance). Physical aggression was not significantly related to emotion regulation strategies, except for its positive correlation with self-blame and a negative one with positive reappraisal. Overall, the most significant positive correlations were found between maladaptive emotion regulation strategies and hostility, as well as anger.

Conversely, in the sample of Ukrainian adolescents, positive correlations were shown between rumination, catastrophizing, total score of maladaptive strategies and anger, as well as hostility. A weak positive relationship was noted between self-blame and hostility. Among adaptive strategies, positive refocusing was weakly positively correlated to anger, whereas positive reappraisal was weakly negatively correlated to hostility. In the sample of Ukrainian adolescents, no relationship between emotion regulation strategies and physical aggression was shown.

\section{Discussion}

The primary aim of the study was to determine the relationship between cognitive coping strategies and forms of aggression in the samples of Polish and Ukrainian adolescents. The analysis showed the presence of significant regularities observed in the two samples, which are important both from the theoretical and practical points of view. It was shown that most maladaptive strategies were strongly related to hostility and, to a somewhat lesser extent, to anger. In contrast, most adaptive strategies were not related to any dimensions of aggression. Only two adaptive emotion regulation strategies, positive reappraisal and positive refocusing, showed negative and weak positive correlations with physical aggression and anger, respectively, across samples. Physical aggression showed almost no correlation with emotion regulation strategies.

It is important to emphasize the unique role of hostility, which is a stable individual difference (Woodall \& Matthews, 1993), in the structure of aggressive behavior. Society condemns the expression of anger or prohibits the expression of physical and verbal aggression with the sanction of punishment. In contrast, there is no disapproval of hostility, which, being a cognitive form of aggression, does not always reveal itself in an explicit form (Larionov, 2020) compared to physical or verbal aggression and anger, which can be easily observed. Thus, the diagnosis of hostility requires special attention. The presence of strong correlation between hostility as a cognitive component of aggression and maladaptive cognitive coping strategies in the conducted study indicates that the hostile person will more often use such strategies as catastrophizing, rumination, self-blame and blaming others, which leads to negative affect (Marszal-Wiśniewska \& Fajkowska, 2010). Larionov's (2020) study in a sample of young adults demonstrated the mediating role of these coping strategies in the relationship between hostility and distress. In this regard, reducing the use of 
maladaptive strategies may decrease the negative effects of hostility in the development of distress.

Analyzing the functional significance of particular maladaptive strategies (self-blame, blaming others, rumination, and catastrophizing) and adaptive strategies (acceptance, refocusing on planning, positive refocusing, positive reappraisal, and putting into perspective), it can be noted that maladaptive strategies intensify negative emotions and weaken positive emotions. In contrast, adaptive strategies facilitate positive emotions and weaken negative emotions (Marszał-Wiśniewska \& Fajkowska, 2010). It is worth noting that the use of adaptive emotion regulation strategies requires adequate effort from the individual, for example: time for some reflection (acceptance), the ability to identify and plan the steps to be taken to cope (refocusing on planning). Using adaptive emotion regulation strategies assumes that the individual already has a high capacity for volitional control and can postpone the adverse reaction. In this regard, one can cite the results of the study by Marszał-Wiśniewska and Fajkowska (2010), which showed that adaptive strategies were related to action orientation in failure and decision-making situations. In contrast, the use of maladaptive strategies was associated with state orientation in these situations. By defining aggressive behavior as "an abnormal form of coping with negative emotional arousal due to difficulties in emotion regulation and cognitive control" (Sołtys \& Grzankowska, 2015, p. 204) it should be noted that the strong relationships between maladaptive coping strategies and the dimensions of aggression are fully valid from a theoretical perspective.

These results lead to important conclusions about the specificity of carrying out psychological interventions aimed at reducing the levels of aggression among adolescents. Since only maladaptive cognitive coping strategies were strongly positively correlated with hostility and anger, while adaptive strategies showed almost no correlation with forms of aggression, several aspects deserve special attention. First, the risk group for aggressive behavior would consist of adolescents prone to self-blame, catastrophizing, rumination, and blaming others. In this sense, the psychological characteristics of such adolescents are a tendency to assign blame to themselves and others for what happened, to think constantly about a negative, unpleasant event and the feelings associated with it, and to emphasize the horror of the event. Secondly, the main goal of prevention activities should be the development of effective coping skills aimed primarily at reducing the use of the maladaptive emotion regulation strategies described above. Thirdly, analyzing the frequency of using particular maladaptive coping strategies both in the sample of Polish and Ukrainian adolescents, it can be noted that adolescents most often use the strategy of ruminating, which is expressed in constant thinking about the negative situation. Garnefski, Legerstee, Kraaij, van den Kommer and Teerds (2002) showed that the strategies of rumination and self-blame were strong predictors of anxiety and depression symptoms among adolescents. Assessing maladaptive cognitive coping strategies may be helpful in identifying adolescents who have 
the increased risk of developing such symptoms as depression and anxiety (Garnefski \& Kraaij, 2014). In this context, a reduction in the use of maladaptive strategies (especially rumination) may contribute to both lower levels of aggression and improved mental health in adolescents.

In a group of adolescents from Ukraine, girls had a significantly higher score in rumination than boys. It is worth noting that although a difference was shown, its level of significance was close to $0.05(p=0.044)$, so the right to draw the conclusion about the particular importance of rumination for girls is limited. Moreover, no such regularity was observed in the Polish sample. However, such pattern of higher tendency to ruminate, which was observed for girls, was also noted in other studies (Chamizo-Nieto, Rey \& SánchezÁlvarez, 2020; Rey \& Extremera, 2012). It is needed to specify this tendency in a larger sample. In conclusion, within their national groups, boys and girls hardly differed concerning the results of the examined variables, which may indicate that gender does not influence the level of aggression and the frequency of using coping strategies in difficult situations. Therefore, psychological assistance programmes based on the development of skills for effective coping can probably be universal for boys and girls.

It is important to emphasize that according to the results of the longitudinal study by Blain-Arcaro and Vaillancourt (2017), aggressive behavior determines the occurrence of depressive symptomatology and not the other way around. The study found that elevated levels of stress, depressive and anxiety symptoms, and increased use of maladaptive coping strategies were more typical for victims of bullying compared to students who were not bullied (Maji, Bhattacharya, \& Ghosh, 2016). According to these data, prevention of aggression in children and adolescents has become increasingly important to protect the mental health of young people.

\section{Limitations of the study}

The study was cross-sectional in nature. In this regard, identification of cause-andeffect relationships is not possible. The study was conducted in a relatively small sample. Therefore, generalization of the results obtained is not fully justified. The questionnaires used were of a self-report type, which is associated with inaccuracy in measurement and a tendency to present oneself in a favorable light, especially when examining aggression (Vigil-Colet, Ruiz-Pamies, Anguiano-Carrasco, \& Lorenzo-Seva, 2012). However, the results of this study are promising because empirically, some common regularities were found in the two cultures, which are consistent with previous theoretical reports and which make an important contribution to understanding the role of cognitive coping in the structure of adolescent aggressive behavior. 


\section{Future directions}

Relying on the empirical results obtained, it seems promising to expand the research. Further studies should be based on the results of a larger research sample. It is also worth focusing on other factors, such as impulsivity and emotional reactivity, which are likely to be moderators of the relationship between emotion regulation strategies and aggression, in order to understand the process of aggressive behavior formation better. And in order to create appropriate psychological assistance programmes for adolescents experiencing aggression, it is not enough to focus solely on the strategies associated with the occurrence of aggression and its diminishment. In this regard, it is also important to examine the factors of the adolescents' external and internal worlds and to what extent they provoke the emergence of aggressive reactions as well as what coping strategies mediate these relationships.

\section{Conclusion}

The results of the study have shown that there is a strong correlation between the frequency of using maladaptive coping strategies (self-blame, blaming others, rumination and catastrophizing) and hostility, as well as anger, among adolescents. It has been confirmed in a sample of Polish and Ukrainian adolescents. This demonstrates the universal nature of this correlation, which is probably independent of cultural characteristics. In the process of aggressive behavior prevention, special attention should be paid to adolescents who are prone to catastrophizing, constantly thinking about an unpleasant event, selfblaming and blaming others. It is very likely that these characteristics predispose to aggressive behavior among young people and to prolonged experiencing stress. In this regard, it is important to pay timely attention to adolescents characterized by the use of maladaptive coping strategies. This will prevent aggressive behavior and improve the mental health of the young generation.

\section{Bibliography:}

Aranowska, E., Rytel, J. (2012). Struktura czynnikowa kwestionariusza agresji Bussa i Perry'ego (BPQA) w populacji polskiej [Factorial structure of the Buss-Perry Aggression Questionnaire (BPQA) in Polish population], Studia Psychologica, 12/2, 135-151.

Aranowska, E., Rytel, J., Szymańska, A. (2015). Kwestionariusz Agresji Bussa-Perry'ego: trafność, rzetelność $i$ normy [The Buss-Perry Aggression Questionnaire: validity, reliability and norms], Warsaw: Instytut AMITY.

Archer, J. (2009). The nature of human aggression, International Journal of Law and Psychiatry, 32(4), 202-208, https:// doi.org/10.1016/j.ijlp.2009.04.001. 
Becelewska, D. (2006). Repetytorium z rozwoju człowieka [Repertory on human development], Jelenia Góra: Kolegium Karkonoskie. Państwowa Wyższa Szkoła Zawodowa.

Benjamin, A.J. (2016). Aggression, (in:) H.S. Friedman (ed.), Encyclopedia of Mental Health (Second Edition), 33-39, Oxford: Academic Press, https://doi.org/10.1016/b978-0-12397045-9.00198-1.

Berkowitz, L. (1993). Aggression: Its causes, consequences, and control, New York: McGraw - Hill.

Blain-Arcaro, C., Vaillancourt, T. (2017). Longitudinal Associations between Depression and Aggression in Children and Adolescents, Journal of abnormal child psychology, 45(5), 959-970, https:/ / doi.org/10.1007/s10802-016-0204-2.

Borzucka-Sitkiewicz, K. (2010). Środowiskowe uwarunkowania agresywnych zachowań młodzieży (jako wyznacznik oddziatywań profilaktycznych i interwencyjnych) [Environmental determinants of aggressive behavior in youth (as a determinant of preventive and intervention actions)], Katowice: Wydawnictwo Uniwersytetu Śląskiego.

Buss, A.H., Perry, M. (1992). The aggression questionnaire, Journal of Personality and Social Psychology, 63(3), 452-459, https:// doi.org/10.1037//0022-3514.63.3.452.

Calvete, E., Orue, I. (2012). The role of emotion regulation in the predictive association between social information processing and aggressive behavior in adolescents, International Journal of Behavioral Development, 36 (5), 338-347, https://doi.org/10.1177/0165025412444079.

Chamizo-Nieto, M.T, Rey, L., Sánchez-Álvarez, N. (2020). Validation of the spanish version of the Cognitive Emotion Regulation Questionnaire in adolescents, Psicothema, 32 (1), 153-159, https:// doi.org/10.7334/psicothema2019.156.

Contardi, A., Imperatori, C., Penzo, I., Del Gatto, C., Farina, B. (2016). The Association among Difficulties in Emotion Regulation, Hostility, and Empathy in a Sample of Young Italian Adults, Frontiers in Psychology, 7, article 1068, https://doi.org/10.3389/fpsyg.2016.01068.

Damięcka, B. (2003). Zjawisko agresji wśród młodzieży szkol średnich jako sposób reakcji na otoczenie [The phenomenon of aggression among high school students as a way of reacting to the environment], Zeszyty Naukowe Ostrotęckiego Towarzystwa Naukowego, $17,190-200$.

Donahue, J.J., Goranson, A.C., McClure, K.S., Van Male, L.M. (2014). Emotion dysregulation, negative affect, and aggression: A moderated, multiple mediator analysis, Personality and Individual Differences, 70, 23-28, https:/ / doi.org/10.1016/j.paid.2014.06.009

Enikolopov, S.N., Tsibul'skii, N.P. (2007). The psychometric analysis of the Russian Version of the Aggression Questionnaire (Buss \& Perry), Psychological Journal, 28 (1), 115-124. 
Garnefski, N., Kraaij, V. (2014). Bully victimization and emotional problems in adolescents: Moderation by specific cognitive coping strategies?, Journal of Adolescence, 37(7), 11531160, https:// doi.org/10.1016/j.adolescence.2014.07.005.

Garnefski, N., Kraaij, V., Spinhoven, P. (2001). Negative life events, cognitive emotion regulation and emotional problems, Personality and Individual Differences, 30(8), 13111327, https:/ / doi.org/10.1016/S0191-8869(00)00113-6.

Garnefski, N., Kraaij, V., Spinhoven, P. (2002). Manual for the use of the cognitive emotion regulation questionnaire, Leiderdorp: DATEC.

Garnefski, N., Kraaij, V., van Etten, M. (2005). Specificity of relations between adolescents' cognitive emotion regulation strategies and Internalizing and Externalizing psychopathology, Journal of Adolescence, 28(5), 619-631, https://doi.org/10.1016/j.adolescence.2004.12.009.

Garnefski, N., Legerstee, J., Kraaij, V., van den Kommer, T., Teerds, J. (2002). Cognitive coping strategies and symptoms of depression and anxiety: a comparison between adolescents and adults, Journal of Adolescence, 25 (6), 603-611, https://doi.org/10.1006/jado.2002.0507.

Gaś, Z. (1980). Inwentarz Psychologiczny Syndromu Agresji [Psychological Inventory of Aggression Syndrome], Przegląd Psychologiczny, 23(1), 143-158.

Inchley, J., Currie, D., Budisavljevic, S., Torsheim, T., Jåstad, A., Cosma, A., i in. (red.). (2020). Spotlight on adolescent health and well-being. Findings from the 2017/2018 Health Behaviour in School-aged Children (HBSC) survey in Europe and Canada. International report. Volume 2. Key data, Copenhagen: WHO Regional Office for Europe.

Jhangiani, R., Tarry, H. (2014). Principles of Social Psychology - 1st International Edition, Victoria, B.C.: BCcampus. Retrieved from https://opentextbc.ca/socialpsychology/ Jurczyk, M. (2018). Relacje między agresywnością a poczuciem napięcia, kontrolą społeczną i kontaktami w środowisku przestępczym wśród uczniów szkół ponadgimnazjalnych [Relations between aggressiveness and a feeling of tension, social control and contacts in crime peer environment among high school students], Psychologia Wychowawcza, 14, 42-62, https:// doi.org/10.5604/01.3001.0012.8281.

Kowalczuk, K., Jankowiak, B., Krajewska-Kułak, E., Rolka, H., Sierakowska, M. (2011). Teorie agresji - prawda czy mity? [Theories of aggression - reality or myths?], Problemy Pielegniarstwa, 19(3), 396-400.

Larionov, P.M., Grechukha, I.A. (2020). The Role of Alexithymia and Cognitive Emotion Regulation in the Development of Aggressive Behavior in Adolescents, Clinical Psychology and Special Education, 9(4), 57-98, https://doi.org/10.17759/cpse.2020090404. 
Larionov, P.M. (2020). The role of hostility and dysfunctional cognitive emotion regulation in the development of psycho-emotional disorders, Psikhologicheskie Issledovaniya, 13(72), 4, http:// psystudy.ru/index.php/num/2020v13n72e/1791-larionov72e.html.

Maji, S., Bhattacharya, S., Ghosh, D. (2016). Cognitive Coping and Psychological Problems among Bullied and Non-bullied Adolescents, Journal of Psychosocial Research, 11(2), 389-398.

Marszał-Wiśniewska, M., Fajkowska, M. (2010). Właściwości psychometryczne Kwestionariusza Poznawczej Regulacji Emocji (Cognitive Emotion Regulation Questionnaire; CERQ) - wyniki badań na polskiej próbie [Psychometic properties of the Cognitive Emotion Regulation Questionnaire (CERQ): Results of the studies on the Polish sample], Studia Psychologiczne, 49 (1), 19-39.

McLaughlin, K.A., Hatzenbuehler, M.L., Mennin, D.S., Nolen-Hoeksema, S. (2011). Emotion dysregulation and adolescent psychopathology: A prospective study, Behaviour Research and Therapy, 49(9), 544-554, https://doi.org/10.1016/j.brat.2011.06.003.

Modecki, K.L., Zimmer-Gembeck, M.J., Guerra, N. (2017). Emotion Regulation, Coping, and Decision Making: Three Linked Skills for Preventing Externalizing Problems in Adolescence, Child Development, 88(2), 417-426, https:/ / doi.org/10.1111/cdev.12734

OECD. (2019). PISA 2018 Results (Volume III): What School Life Means for Students' Lives, Paris: PISA, OECD Publishing, https://doi.org/10.1787/acd78851-en.

Pikuła, N. (2012). The Phenomenon of Aggression as a social problem, E-Theologos. Theological revue of Greek Catholic Theological Faculty, 3(1), 38-51, https:/ / doi.org/10.2478/v10154012-0004-y.

Porzak, R. (red.). (2019). Profilaktyka w szkole [Prevention at school], Lublin: Fundacja "Masz Szansę".

Przybysz-Zaremba, M. (2015). Egzemplifikacje wybranych teorii zachowań agresywnych człowieka - perspektywa trójwymiarowa [Exemplifications of chosen theories on human's aggressive behaviours - prospect three-dimensional], Studia nad Rodzina, 2(37), 311-332.

Rasskazova, E.I., Leonova, A.B., Pluzhnikov, I.V. (2011). Development of the Russian version of the Cognitive Emotion Regulation Questionnaire, Moscow University Psychology Bulletin, 4, 161-179.

Rey, L., Extremera, N. (2012). Physical-Verbal Aggression and Depression in Adolescents: The Role of Cognitive Emotion Regulation Strategies, Universitas Psychologica, 11(4), 1245-1254.

Roberton, T., Daffern, M., Bucks, R.S. (2012). Emotion regulation and aggression, Aggression and Violent Behavior, 17(1), 72-82, https:/ / doi.org/10.1016/j.avb.2011.09.006.

Rozporządzenie Ministra Edukacji Narodowej i Sportu z dnia 31 października 2018 r. w sprawie bezpieczeństwa i higieny $\mathrm{w}$ publicznych i niepublicznych szkołach i 
placówkach (Dz. U. z 2018 r. poz. 2140 ze zm.) [Regulation of the Minister of National Education and Sport, concerning safety and hygiene in public and non-public schools and institutions, issued on 31 October 2018 (Dz. U. of 2018, item 2140)].

Rozporządzenie Ministra Edukacji Narodowej z dnia 28 sierpnia 2017 roku zmieniające rozporządzenie $\mathrm{w}$ sprawie zasad udzielania i organizacji pomocy psychologicznopedagogicznej w publicznych przedszkolach, szkołach i placówkach (Dz. U. z dnia 31 sierpnia 2017 roku, poz. 1643) [Regulation of the Minister of National Education, amending the regulation on the principles of providing and organizing psychological and pedagogical assistance in public kindergartens, schools and other institutions, issued on 28 August 2017 (Dz. U. of 31 August 2017, item 1643)].

Sołtys, M., Grzankowska, I. (2015). Emocjonalność rodziców a natężenie zachowań agresywnych $\mathrm{u}$ dzieci [Emotionality of parents and aggressive behaviour among children], Polskie Forum Psychologiczne, 20(2), 201-215, https://doi.org/10.14656/PFP20150204.

Sukhodolsky, D.G., Smith, S.D., McCauley, S.A., Ibrahim, K., Piasecka, J.B. (2016). Behavioral Interventions for Anger, Irritability, and Aggression in Children and Adolescents, Journal of Child and Adolescent Osychopharmacology, 26(1), 58-64, https://doi.org/10.1089/cap.2015.0120.

Valois, R.F., MacDonald, J.M., Bretous, L., Fischer, M.A., Drane, J.W. (2002). Risk factors and behaviors associated with adolescent violence and aggression, American journal of health behavior, 26(6), 454-464, https:// doi.org/10.5993/ajhb.26.6.6.

Vigil-Colet, A., Ruiz-Pamies, M., Anguiano-Carrasco, C., Lorenzo-Seva, U. (2012). The impact of social desirability on psychometric measures of aggression, Psicothema, 24(2), 310-315.

Woodall, K.L., Matthews, K.A. (1993). Changes in and stability of hostile characteristics: results from a 4-year longitudinal study of children, Journal of Personality and Social Psychology, 64 (3), 491-499, https:/ / doi.org/10.1037/ /0022-3514.64.3.491.

World Health Organization, Geneva: World Health Organization, https://apps.who.int/iris/handle/10665/44089.

World Health Organization, (2014). Global status report on violence prevention 2014, Geneva: World Health Organization, https://www.who.int/violence_injury_prevention/violence/status_report/2014/en/. 